\title{
A Study of the Relationship between English Teachers' Approaches to Teaching and Students' Incivilities
}

\author{
Maryam Sadat Nezamedini \\ Department of English, Faculty of Literature \& Foreign Languages \\ University of Kashan, P.O. Box 87317-51167, Iran \\ E-mail: m.nezamedini@gmail.com \\ Ali Rahimi (Corresponding author) \\ Bahcesehir University, Istanbul, Turkey \\ E-mail: rahimi_cda@yahoo.com; ali.rahimi@bahcesehir.edu.tr
}

Seyed Ahmad Madani Borujeni

Department of Education, University of Kashan, P.O. Box. 87317-51167, Iran

E-mail: madani.edu@gmail.com

Received: January 21, 2013 Accepted: March 21, 2013 Published: March 24, 2013

doi:10.5296/ijele.v1i1.3429 URL: http://dx.doi.org/10.5296/ijele.v1i1.3429

\begin{abstract}
This article aims at investigating the relationship between English instructors' approaches to teaching and student incivilities in their classrooms. Previous studies revealed that student incivility could be influenced by variables such as class size, subject matter, and academic achievement. In this study, 137 English instructors filled in two sets of questionnaires, one probing into the instructors' approaches to teaching and the other asking for student incivility. The results indicated that the facilitative teachers reported to have encountered fewer students' incivilities in classrooms. The importance of this finding is that an instructor's belief in a certain instructional school of thought can deeply influence his or her conception of students' incivilities in a way that he or she does not even notice these incivilities in the classroom.
\end{abstract}

Keywords: Teaching, Teaching approaches, Executive approach, Facilitator approach, Liberationist approach, Student incivility, classroom management 


\section{Introduction}

Teaching is well-nigh the point of the whole educational enterprise and establishment aimed at producing students' learning (Gage, 2009). As Freeman and Richards (1993) put it, teaching is defined in various terms such as a science, a technology, a craft, or an art. "Each of these characterizations carries with it defined orientations towards what teaching is, what essential skills it involves, and what teachers must know. They also contribute to defining different approaches to the preparation of teachers" (p. 193). The term approach indicates a set of beliefs, whether explicit or implicit, about teaching and teacher's work, including underlying assumptions. To be considered an approach, this set of beliefs must be sufficiently consistent and comprehensive to represent a reasonable guide for coherent thinking and acting in teaching. Other words sometimes used to describe the term approach are an image, an orientation, a perspective, or a position (Jarvis, 2006). Irrespective of the term used to describe the concept of approach, teachers' educational beliefs influence what they do and how they teach in the classroom (Connelly \& Ben-Peretz, 1980; Connelly and Elbaz, 1980; Gutek, 2006). Hawthorne (1990) asserts that teachers' beliefs towards learners, learning, teaching, and curriculum directly influence what and how teachers teach.

McCutcheon (1985) also maintains that teachers' decision making is influenced by their educational theories. She explains that teachers' and administrators' theories of action, which are the set of constructs, beliefs, and principles on which practitioners base decisions and actions, illuminate and guide practitioners' work because they comprise interrelated sets of interpretations about what should be taught and learned, how to improve and evaluate teaching and learning, and how to manage classes and work.

Investigating teachers' approaches to teaching can assist us in identifying other variable which are associated with these approaches. Various studies, for instance, have been conducted and demonstrated the relationship between approaches to teaching and variables such as conceptions of teaching (Lam \& Kember, 2006), discipline and teaching context (Lindblom-Ylänne, Trigwell, Nevgi, \& Ashwin, 2006), and students' approaches to learning (Trigwell, Prosser, \& Waterhouse, 1999). In addition, several researches have suggested that teachers' goals for engaging students affect the organization of course content, the construction of course activities, and the quality of teacher-student interactions (Barr \& Tagg, 1995; Chickering \& Gamson, 1999; Morrone \& Tarr, 2005).

Student incivility is one of the variables which is particularly of utmost importance to lecturers at the level of higher education and can sometimes strongly influence the quality of teaching and learning in classrooms. Feldman (2001) believes that examining our attitudes and teaching methods enables us to considerably decrease the number and magnitude of the instances of incivility. Dealing with classroom incivilities is one of the most challenging and prevalent aspects of being a teacher. Although instructors might be experts in their content areas, they often have little knowledge of interpersonal dynamics and hardly any training in dealing with students. Yet they want to create an environment of mutual respect which is obviously not rife with frictions and controversies (Boice, 1992). There is no uniform definition the term "incivility" and that appears to be the major reason for not only the public 
but also the instructor' bafflement. Incivilities can sometimes simply consist of behaviors that lack civility and consideration for others. If we define incivilities in this way, it is clear that they are not necessarily grounds for any kind of formal legal intervention. (Bottoms, 2006) Merrett and Wheldall (1984) defined disruptive classroom behavior as activities that interfere significantly with a student's own learning, another student's learning or responses, the teacher's ability to operate effectively, or any combination of these. Feldman (2001) defined classroom incivility as any action that hiders a "harmonious and cooperative learning atmosphere in the classroom" (p. 137). Incivilities can be either covert behaviors (sleeping, arriving to class late, leaving class early) or overt behaviors (talking in class, using cell phones, eating and drinking noisily, arguing with instructors) (Meyers, 2003; Seidman 2005). Goodyear et al. (2010) defined three types of student incivility: 1) student disengagement, 2) general disruptive behavior, and 3) behaviors directed specifically at the instructor. Sorcinelli (1994) ascertains that examples of classroom incivilities include (1) Talking and inattention (2) Unpreparedness and missed deadlines (3) Lateness and in attendance and (4) Direct challenges to authority. In order to define the concept of classroom incivility, Boice (1996) provides some typical examples of such kinds of actions including: "missing classes, cheating, refusing to participate, coming unprepared, and distracting teachers and other students" (p. 458). Obviously, more research should be constructed in order to clarify teachers' perception of "incivility", and to ascertain the extent to which those incivilities exist in classrooms. All in all, students' incivilities can be regarded as a series of behaviors which, from the teachers' points of view, may disrupt the teaching-learning process, or interfere with the process of instruction.

Regardless of the type of student incivility, teachers often feel frustrated, distressed, and even fearful in their own classrooms (Barbetta, Norona \& Bicard, 2005; Ennis, 1996; Hernandez \& Fister, 2001; Meyers, 2003; Seidman, 2005; Young, 2003). An instructor may even reach the point of dreading teaching a class. Intense encounters can affect the learning environment, an instructor's ability to teach, and overall emotional well-being (Boice, 1996; Morrissette, 2001). In addition, Students who act appropriately in the class also often feel annoyed and even angry by their classmate's inappropriate behavior (Hirschy \& Braxton, 2004). Many students expressed frustration about how teachers dealt with classroom incivility (Hirschy \& Braxton, 2004; Seidman, 2005). The literature revealed that those students whose behaviors are acceptable and appropriate were found to have negative thoughts and feelings about these ineffective teachers and the institution itself (Hirschy \& Braxton, 2004; Meyers, 2003; Seidman, 2005).

Through managing students' behavior in the classroom and creating a positive learning environment, teachers might be able to not only teach more efficiently but also provide more assistance to students with their academic achievement (Wentzel, 2002; Shin \& Koh, 2007). The way teachers behave will influence pupils' behavior, and because teaching styles and approaches are patterns of behavior which differ, they will affect students differently (Murphy \&Brown, 1970). According to Feldman (2001) "we can greatly reduce the number and magnitude of the instances of incivility by examining our attitudes and teaching methods (p. 137). 
The results of exploring the relationship between teachers' approaches to teaching and students' incivilities will help teachers reflect on their current approaches to teaching and adopt an approach which can reduce the number of students' misbehaviors to the least possible. Obviously, teachers' approaches to teaching can be an integration of two or more approaches. As a result, the purpose of the current study is to examine the probable relationship between instructors' approaches to teaching, through incorporating two questionnaires, one constructed on the basis of Fenstermacher and Soltis (2004) classification of approaches for the purpose of determining teachers' conception of their approaches to teaching and the other developed to identify the kinds and measure the frequency of occurrence of students' incivilities in English classrooms.

\section{Approaches to Teaching}

Various scholars have attempted to provide frameworks and classify teaching approaches with the aim of helping teachers teach more effectively, and create a more positive classroom environment (Banning, 2005; Fenstermacher \& Soltis, 2004; Grasha, 2002; Trigwell, Prosser \& Waterhouse, 1999; Kember \& Gow, 1994; Trigwell, Prosser \& Taylor, 1994; Trigwell \& Prosser, 1991). Banning (2005), for instance, suggests a classification for teaching approaches which places teaching styles into three main categories: didactic, Socratic, and facilitative.

Knowledge transmission and learning facilitation are two orientations to lecturers' teaching in higher education proposed by Kember and Gow (1994). Furthermore, researchers distinguish between teacher-centered approaches and student-centered approaches to teaching (Prosser, Trigwell \& Taylor, 1994; Trigwell \& Prosser, 1996 a; Prosser \& Trigwell, 1999). Barr and Tagg (1995) also identified two teaching paradigms called Instruction and Learning. Depending on the way teachers view the process of teaching, they may adopt different teaching approaches. Trigwell, Prosser and Taylor (1994) identified five different approaches to teaching: (A) A teacher-focused strategy with the intention of transmitting information to students; (B) A teacher-focused strategy with the intention that students acquire the concepts of the discipline; (C) A teacher/student interaction strategy with the intention that students acquire the concepts of the discipline; (D) A student-focused strategy aimed at students developing their conceptions; and (E) A student-focused strategy aimed at students changing their conceptions.

Barr and Tagg (1995) also identified two teaching paradigms called Instruction and Learning. Another approach to conceptualizing teaching and learning in higher education is "teaching perspectives" of Dan Pratt (Pratt, 1992; Pratt, 1997; Pratt \& Associates, 1998; Pratt \& Collins, 2001). Pratt (1998) developed five perspectives of teaching: Transmission, Apprenticeship, Developmental, Nurturing, and Social Reform. In a similar vein, Grasha's (2002) suggests five pervasive teaching styles which are as follows: expert, formal authority, personal model, facilitator, and delegator.

\subsection{Fenstermacher and Soltis's Approaches to Teaching}

Fenstermacher and Soltis (2004) suggest that there are three basic approaches to teaching: 
Executive, Facilitator and Liberationist. To compare and contrast these three approaches to teaching, they developed the MAKER framework. This framework relates to five aspects of teaching: Method (M), Awareness (A), Knowledge (K), Ends (E), and Relationship (R). Method is mostly concerned with how teachers teach, or what skills and techniques they bring to the classroom. Awareness pertains to what teachers know about their students. Knowledge refers to what teachers know about the subject matter that is being taught. Ends relates to teachers' goals for their teaching and their students. The fifth and the last element, Relationship, refers to how the teachers bond with their students.

\subsection{The Executive Approach}

The executive approach is the first approach to teaching presented by Fenstermacher and Soltis (2004). According to this approach instructor is the manager of complex classroom processes whose main responsibility is using the best materials, skills, techniques, and methods of teaching which are available to him/her to produce certain outcomes with students. Fenstermacher and Soltis (2004) trace the origin of this theory to the behaviorist, positivist views.

The overall aim of the executive teacher is transmitting a body of knowledge or skill that students are to acquire and selecting certain methods of instruction that are most effective in conveying this body of knowledge. Thus, the executive approach primarily focuses on $\mathrm{M}$ (Methods of teaching) and K (Knowledge of subject matter) and other elements of the MAKER framework, A (Awareness of one's students), E (Ends that guide the activities of teaching and learning), and R (Relationships between teacher and students), are given little attention. The executive approach typically defines knowledge $(\mathrm{K})$ as "something "out there," external to the teacher and the learner, with the teacher serving as a conveyor of that knowledge to the student" (p. 17). Prior experiences of the learners are not emphasized and students are believed to be without knowledge when they arrive in the classroom.

\subsection{The Facilitator Approach}

The second approach proposed by Fenstermacher and Soltis (2004) is the facilitator approach. This approach views the instructor as a human being whose mission is to help students become self-actualized individuals. The facilitative teacher places a high value on what students bring to the classroom setting and puts considerable emphasis on students' prior experiences. Humanistic psychology, learning theory, and existential philosophy are some of the fields of scholarship that lend support to this view. On the MAKER framework, awareness of the students (A) and Ends (E) are integral parts of the facilitator approach. The concept of relationship (R), however, is not as crucial in the mainstream facilitator approach as it is in care pedagogy, the variant of this approach. Learning theory, humanistic psychology, and existential philosophy underwrite the facilitator approach to teaching.

\subsection{The Liberationist Approach}

The third and the last approach named the liberationist approach has two strands. The first strand, or the mainstream version of this approach, views the teacher as a person who frees and opens the learners' mind, and helps them become moral human beings. The liberationist 
approach is rooted in notions of liberal education. Liberal education in general and the liberationist approach in particular stresses initiation into ways of knowing and the development of the student's intellectual and moral virtues. The liberationist approach attaches primary importance to Knowledge $(\mathrm{K})$ and end $(\mathrm{E})$ elements of the MAKER framework. The liberationist approach places some strict controls on what can be considered as Knowledge, and as a result on what is proper to the curriculum. The end of education, in the liberationist approach, is for learners to take up membership in civilized life.

As Fenstermacher and Soltis (2004) pointed out, in view of the fact that many atrocities have been committed by those who have extensive knowledge, the liberationist does aim at developing persons who are solely knowledgeable, but "persons who are also just and loving, who are imaginative in thought and discerning in conduct, and who are committed to the advancement of humankind" (p. 46). Emancipatory teaching is the variant of the liberationist approach which emphasizes action over contemplation. "It typically addresses this orientation to action by making real social, political, and economic problems the focus of the curriculum and by introducing subjects of study as these bear on the resolution of the problems posed" ( $p$. 59)

According to Fenstermacher and Soltis (2004), it is not sufficient for teachers to rigidly follow the script of a facilitator approach, executive approach or liberationist approach. Teachers should delve into the ideas behind each of the three approaches. This will enable them to discover where they stand relative to these three approaches. Fenstermacher and Soltis (2004) believe that it is important for teachers to be comfortable with all three approaches. Even though every teacher may have a preferred approach, for certain instructional situations one or more of these three approaches might be more effective. Using all three of these approaches prepares one "to function well in different school settings, with different learners, who are in various stages of development at any given moment and posses a huge diversity of temperaments, needs, and interests" (p. 73). The authors argue that it is not important what name a teacher attributes to his or her own approach to teaching, what matters is what one really believes the purposes of teaching to be and what it means to be an educated person. They later state that thinking seriously about the different approaches is not only an academic exercise, but it is essential to helping one become the kind of teacher he or she wants to be.

\section{Student Incivility}

Hernandez and Fister (2001) characterize students' classroom incivilities as rebellious, emotional, or escalating in nature. Appleby (1990) found considerable consensus among instructors and faculty members about student behaviors that they perceive to be most irritating and subsequently affecting the teaching learning process most negatively. Behaviors were put into three categories: (1) immature behaviors such as talking in the classroom, chewing gum, and disturbing the class; (2) inattentive behaviors such as sleeping during class, cutting class, and not paying attention; and (3) miscellaneous behaviors such as cheating and expressing more interest in grades than in learning.

Feldman (2001) grouped student incivility into four constructs: 1) annoyances 2) Classroom 
terrorism 3) Intimidation 4) Uncivil actions that involve violence towards an individual 5) Attacks and assault on the psyche of the teacher. Boice (1996) classified the most frequent classroom incivilities into three groups. These groups are formed on the basis of students', teachers', or both students and teachers' views. According to Boice (1996) both students and instructors are bothered by students who (a) converse so loudly that lecturers and student discussants could not be heard the rest of the class, (b) confront teachers with loud sarcastic remarks, or (c) are considered to be "classroom terrorists" and make unpredictable or emotional outbursts. What bothers students about their teachers are (a) teachers' uncaring behavior; Teachers' surprising them with unexpected test items and grades; (b) Teachers' arriving late at the class or canceling the class without advanced warning; students also resent students who (c) belittle their fellow classmates. Instructors are annoyed by students who (a) are reluctant to participate class activities, (b) attend classes unprepared, (c) impose by demanding extended deadlines or make-up exams, or (d) arrive late or leave early, disruptively.

Even though students do not always behave in class the way teachers expect them to, instructors are reluctant to confront them. Weimer (1988) has proposed several reasons for that. First, instructors tend to ignore student offenses in the classroom because they consider them not to be egregious, and as a result avoid confronting them rather than making a scene. Second, instructors hesitate to deal with students' disruptive behaviors mainly because they feel these behaviors are due to some deficiency in their teaching. Finally, instructors may be reluctant to deal with incivilities because they do not know or are unsure of what they ought to do. Addressing the same problem, Amada (1999) states that fear of the consequences of confronting student incivilities may cause teachers to remain silent about misbehaviors in the classroom.

However, instructors are advised not to postpone disciplining students for two basic reasons. First, failure to address troublesome behaviors has a negative influence on the learning environment. And second, confronting classroom incivilities can prevent future misbehaviors from the same and other students. (Feldmann, 2001) Students misbehave for a variety of reasons. Knowing the reason can assist the teacher to adopt the most appropriate intervention strategies possible. A range of variables, usually in combination, shape the behavior of individuals (Ridley \& Walther, 1995). These variables are deemed to be either internal or external to the individual. Internal variables include biological factors (e.g. the state of the nervous system and certain glandular functions, heredity and other genetic considerations), and psychological factors (e.g. levels of self-concept, anxiety, intelligence and motivation). External variables encompass any environmental influences of which the family, school and peer group seem to be the most influential. The intricate interaction between these variables will affect how (and what) we think, feel and act (Charlton, 2003).

In a less complex categorization, researchers have grouped factors contributing to individuals' behavior problems into: predisposing, precipitating and reinforcing causes (Charlton, 2003).

However, it is essential to note that, causes of students' misbehaviors are far more complex 
than the previous paragraphs perhaps imply. In fact, a host of contributory factors interact to lead to behavioral problems of an individual. Bray and Del Favero (2004) clearly state that classroom incivilities are not unidirectional and they do not take place in a vacuum. Bray and Del Favero(2004) provide some sociological theories that can help explain how classroom incivilities happen and how they can be handled. These sociological theories include: social control theory, deterrence theory, rational choice theory, anomie, social exchange theory, and social bond theory.

\section{Sociological Explanations}

Although college students misbehavior is not a new notion and a plethora of researches about this topic have been conducted (Barbetta, Norona \& Bicard 2005; Seidman, 2005; Meyers, 2003; Young, 2003; Hernandez \& Fister, 2001), there is a growing belief among both teachers and administrators that the number of students' incivilities is increasing in colleges (Feldman, 2001; Harris, 1996; Morrissette, 2001; Richardson, 1999; Boice, 1996). Teachers have reported of students assaulting them, stalking them, challenging them to fights, and sending hateful e-mails (Hernandez \& Fister, 2001). These extreme examples clearly indicate a power struggle between students and instructors.

Getting education for the purpose of broadening one's intellectual capacity is no longer the reason for students' attending universities, rather there has been a conscious paradigm shift from this notion to the idea that a college education paves the way to high paying job (Hernandez \& Fister, 2001). Furthermore, many students view their education as a product they are paying for (Oblinger, 2003). This kind of perspective has unintended consequences. These students (who regard themselves as consumers) often make unrealistic demands on teachers and administrators (Hernandez \& Fister, 2001; Young, 2003). The literature revealed many college students also see professors as gatekeepers (rather than intellectual leaders) who impede the students' progress, and do not let them complete their college education and get their desired better job.( Lippmann, Bulanda, \& Wagenaar, 2009)

Violence or the threat of violence against college faculty is perhaps the greatest form of classroom incivility (Boice, 1996; Feldman, 2001; Hernandez \& Fister 2001). Hernandez and Fister asserted that, "Instructors, using only the authority of their position are no longer able to maintain decorum in the classrooms or a sense of personal safety" (p. 49). This might be mainly due to the behavioral choices (Glasser, 1998) and characteristics of the modern student (Hernandez \& Fister, 2001). "Students in today's colleges and universities also have a blurry perception of the boundaries between themselves and the faculty, staff, and administration. College students tend to see themselves as the hub around which society revolves" (Hernandez \& Fister, 2001, p. 53). As result of such kinds of feelings many students believe their needs are paramount and must come first (Glasser, 1998). Instructors have reported being stalked by their students, receiving alarming e-mails, strange voicemails (Amada, 1995; Amada, 1997; Hernandez \& Fister, 2001). Although acts of violence against college faculty are rare, they have occurred (Boice, 1996; Feldman, 2001; Hernandez \& Fister 2001).

To deal with such matters, several researchers have suggested different strategies and 
measures. Sorcinelli (1994), for instance, offers four strategies that teachers can utilize to create a positive classroom environment: outline expectations for student behavior in the class, reduce student anonymity, ask for students' feedback, and encourage students to learn actively. Feldman (2001) notes that proactive and reactive measures can be taken by instructors to avoid misbehaviors in the classroom. Charles (2008) argues that classroom discipline must be approached proactively and not reactively. He believes that having classroom rules which are limited in number and stated in a positive manner is essential to classroom discipline. In fact, a teacher cannot expect his or her students to behave appropriately in the classroom without teaching them how to act appropriately.

\section{Method}

\subsection{Participants}

The target population was all teachers who specialized in teaching English. Participants in the study were comprised of lecturers teaching at the university level and English teachers working in English teaching institutes of the city of Isfahan. There are three elements required to estimate sample size needed for a study: (a) significance level, (b) desired power, and (c) effect size (Cohen, 1988). In this study, the statistical significant level selected was a $\mathrm{P}$ value of $0 / 05$, the desired power was $0 / 8$ and the estimated effect size chosen for this study was $0 / 50$. Few have studied the relationship between teachers' approaches to teaching and student incivilities. Thus, a medium effect size of $0 / 5$ was used in this study. Using G*power software (Erdfelder, Faul \& Uchner, 1996), this set of condition required 129 subjects using Multiple Regression as statistical test. The number of participants $(n=137)$ was more than the required subjects for this study.

\subsection{Instrument}

The main source of information used to create the questionnaire was the defining characteristics of three major approaches to teaching from the viewpoint of Fenstermacher \& Soltis (2004). The instrument consists of 39 Likert-type scale questions that address multiple dimensions related to the teacher's approaches to teaching. The instrument is comprehensive in order to address all components of an approach. The teaching questionnaire is divided into three separate subscales: (1) executive approach, (2) facilitative approach, and (3) liberationist approach. Validity evidence (i.e., content validity evidence and construct validity evidence) as well as reliability evidence (i.e., internal consistency reliability evidence and stability reliability evidence) has been collected on this instrument. The questionnaire was derived from the relevant literature and pre-existing measurement tools, such as instruments designed by Trigwell, Prosser and Taylor (1994); Pratt (1992); and Jarvis-Selinger, et al. (2007), all of which assess teaching styles.

In the determination of content validity, a conceptual framework was established and then a comprehensive questionnaire was developed based on an extensive literature review and the opinion of professionals in the field. Participants were asked to judge each statement from the viewpoint of "This is what I really believe" and not "This is how it is now". The aim of this section is to show an individual consistency or lack of it in choosing teaching approaches. 


\section{Macrothink}

Research findings and theoretical literature of the field of teaching confirm the fact that the current procedure adopted at the higher education level and English teaching institutions tends to lead the instructors towards certain teaching practices and ways of thinking. As a result, the items of the questionnaire, especially those related to the executive approach, were designed in a way that they mostly measured the fundamental conceptions of a specific teaching approach. In fact, instead of considering instructors' practical dimensions and indicators, which are unavoidably evident in teachers' styles and practices, theoretical and intellectual foundations of the approaches, particularly those of the executive approach, were taken into account in designing the items of the questionnaire. Coefficient alpha analysis for scale reliability has demonstrated high levels of reliability for this instrument: The internal consistency reliability coefficient (Cronbach's Alpha) for Approaches to Teaching Questionnaire was 0/814.

The second questionnaire was prepared to probe into teachers' views about their students' incivilities. The nature of student incivility is almost the same in different instructional settings. Nevertheless, to take cultural differences, which are of paramount importance in designing questionnaires, into account, only those items which were thought by the instructors to be typical examples of misbehaviors and incivilities were analyzed. This is shown in table 1 below.

Table 1. Typical examples of misbehaviors and incivilities

\begin{tabular}{|c|c|c|c|c|c|c|c|c|c|c|c|}
\hline \multicolumn{6}{|c|}{$\begin{array}{l}\text { Such behaviors are unacceptable } \\
\text { and inappropriate... }\end{array}$} & \multicolumn{6}{|c|}{$\begin{array}{l}\text { In my classes I encounter } \\
\text { students who....... }\end{array}$} \\
\hline $\begin{array}{l}\stackrel{\leftrightarrow}{g} \\
\stackrel{3}{2} \\
\stackrel{0}{\&}\end{array}$ & $\stackrel{5}{\&}$ & 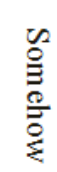 & 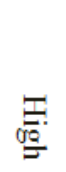 & 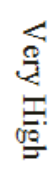 & & & $\underset{@}{Z}$ & 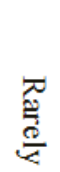 & 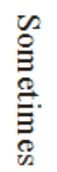 & 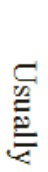 & $\stackrel{\varrho}{\stackrel{\varrho}{\varrho}}$ \\
\hline \multirow[t]{3}{*}{5} & 4 & 3 & 2 & 1 & Disrupt & & 1 & 2 & 3 & 4 & 5 \\
\hline & & & & & $\begin{array}{l}\text { Have } \\
\text { attentio }\end{array}$ & cher's & & & & & \\
\hline & & & & & Groan & & & & & & \\
\hline
\end{tabular}

As shown in table 1, the questionnaire related to students' incivilities is designed in a way to measure not only the frequency of occurrence of each of the incivilities, but also the nature of these incivilities from the view point of the instructors. In the process of data analysis, only those items which were identified by the instructors to be typical examples of incivilities and disruptive behaviors were analyzed.

\section{Results}

Is there a relationship between English teachers' executive, facilitative, or liberationist approaches to teaching; and students' incivilities in English classrooms? 
Multiple regression analysis was used in order to answer this question. For this purpose, primarily the relationship between every one of the predictor variables (i.e. teaching approaches) and outcome variable (i.e. student incivility) was explored. Table 2 sets out the correlation between these variables.

Table 2. The correlation between student incivility and the executive, the facilitator and the liberationist approaches to teaching

\begin{tabular}{|l|l|l|l|l|l|}
\hline \multicolumn{2}{|l|}{ Approaches to Teaching } & $\begin{array}{l}\text { Executi } \\
\text { ve }\end{array}$ & $\begin{array}{l}\text { Facilitat } \\
\text { or }\end{array}$ & $\begin{array}{l}\text { Liberationi } \\
\text { st }\end{array}$ & $\begin{array}{l}\text { Incivilit } \\
\text { y }\end{array}$ \\
\hline \multirow{3}{*}{ Incivility } & $\begin{array}{l}\text { Pearson } \\
\text { Correlation }\end{array}$ & .164 & -.470 & -.101 & 1 \\
\cline { 2 - 6 } & Sig. (2-tailed) & .055 & .000 & .240 & \\
\cline { 2 - 6 } & $\mathrm{N}$ & 137 & 137 & 137 & 137 \\
\hline
\end{tabular}

As illustrated in Table 2, there is a significant and negative correlation between the facilitator approach and student incivility $(\mathrm{r}=-0.470 \leqq \mathrm{P}=0.0001)$. That is the more similarity is observed between the instructors' beliefs and the basic assumptions of the facilitators approach, the fewer number of student incivility is reported. Additionally, a significant correlation between the executive approach and student incivility is observed. Even so this correlation is meaningful at the level of $90 \%$, this significance is sufficient to make it possible for the executive approach to find its way to multiple regression analysis as the second predictor variable.

As shown in Table 2 the regression of student incivility on the executive approach is significant at the level of $90 \%$. The B-slope $(\beta)$ and intercept $(\alpha)$ vales are reported in table 2 :

Table 3. The regression coefficient of student incivility on the executive approach

\begin{tabular}{|c|c|c|c|c|c|c|}
\hline \multirow{2}{*}{\multicolumn{2}{|c|}{ Model }} & \multicolumn{2}{|c|}{$\begin{array}{l}\text { Unstandardized } \\
\text { Coefficients }\end{array}$} & \multirow{2}{*}{$\begin{array}{l}\text { Standardiz } \\
\text { ed } \\
\text { Coefficient } \\
\text { s } \\
\text { Beta }\end{array}$} & \multirow[t]{2}{*}{$\mathrm{t}$} & \multirow[t]{2}{*}{$P$} \\
\hline & & $\mathrm{B}$ & Std. Error & & & \\
\hline 1 & (Constant) & 21.148 & 2.365 & & 8.942 & .000 \\
\hline & Executive & .102 & .052 & .164 & 1.937 & .055 \\
\hline
\end{tabular}

As Table 3 depicts, the unstandardized regression coefficient between student incivility and the executive approach is 0.102 . This coefficient means that every unit of increase on the 
horizontal axis will result in 0.102 unit of increase along the vertical axis. The constant value $(\alpha)$ equals 21.148. The standardized regression coefficient is 0.164 . It is therefore possible to predict the rate of student incivility which might be encountered from an instructor's score in the executive approach. The prediction equation is as follows: $\gamma=21.148+(0.102 \mathrm{X})$. In this equation, $\mathrm{x}$ represents an instructor's score in the executive approach, and $\gamma$ represents the best predication of incivility score.

As shown in table 4 the regression of student incivility on the facilitator approach is significant at the level of $95 \%$. The B-slope $(\beta)$ and intercept $(\alpha)$ vales are reported in table 3:

Table 4. The regression of student incivility on the facilitator approach

\begin{tabular}{|l|l|l|l|l|l|l|}
\hline \multicolumn{2}{|l|}{ Model } & $\begin{array}{l}\text { Sum of } \\
\text { Squares }\end{array}$ & df & $\begin{array}{l}\text { Mean } \\
\text { Square }\end{array}$ & F & $\begin{array}{l}\text { Sig } \\
.\end{array}$ \\
\hline \multirow{2}{*}{1} & Regression & 448.380 & 1 & 448.380 & $\begin{array}{l}38.1 \\
87\end{array}$ & $\begin{array}{l}.00 \\
0^{\mathrm{a}}\end{array}$ \\
\cline { 2 - 7 } & Residual & 1585.124 & 135 & 11.742 & & \\
\cline { 2 - 7 } & Total & 2033.504 & 136 & & & \\
\hline
\end{tabular}

a. Predictors: (Constant), Facilitator

b. Dependent Variable: Incivility

As Table 5 depicts, the unstandardized regression coefficient between student incivility and the facilitator approach is -0.249 . This coefficient means that every unit of increase on the horizontal axis will result in -0.249 unit of increase along the vertical axis.

Table 5. The regression coefficient of student incivility on the facilitator approach

\begin{tabular}{|c|c|c|c|c|c|c|}
\hline \multirow{2}{*}{\multicolumn{2}{|c|}{ Model }} & \multicolumn{2}{|c|}{$\begin{array}{l}\text { Unstandardized } \\
\text { Coefficients }\end{array}$} & \multirow{2}{*}{$\begin{array}{l}\text { Standardiz } \\
\text { ed } \\
\text { Coefficien } \\
\text { ts } \\
\text { Beta }\end{array}$} & \multirow[t]{2}{*}{$\mathrm{t}$} & \multirow[t]{2}{*}{ Sig. } \\
\hline & & B & $\begin{array}{l}\text { Std. } \\
\text { Error }\end{array}$ & & & \\
\hline 1 & $\begin{array}{l}\text { (Constan } \\
\text { t) }\end{array}$ & 36.315 & 1.745 & & $\begin{array}{l}20.81 \\
4\end{array}$ & .000 \\
\hline & $\begin{array}{l}\text { Facilitat } \\
\text { or }\end{array}$ & -.249 & .040 & -.470 & $\begin{array}{l}-6.18 \\
0\end{array}$ & .000 \\
\hline
\end{tabular}


The constant value $(\alpha)$ equals 36.315 . The standardized regression coefficient is -0.470 . It is therefore possible to predict the rate of student incivility which might be encountered from an instructor's score in the facilitator approach. The prediction equation is as follows: $\gamma=36.315+(-0.249 X)$. In this equation, $x$ represents and instructor's score in the facilitator approach, and $\gamma$ represents the best predication of incivility score.

Table 6. The regression coefficient of student incivility on the liberationist approach

\begin{tabular}{|c|c|c|c|c|c|}
\hline Model & $\begin{array}{ll}\text { Sum of } \\
\text { Squares }\end{array}$ & $\mathrm{df}$ & $\begin{array}{l}\text { Mean } \\
\text { Square }\end{array}$ & $\mathrm{F}$ & Sig. \\
\hline $1 \mid \begin{array}{l}\text { Regressi } \\
\text { on }\end{array}$ & 20.770 & 1 & 20.770 & 1.393 & $\begin{array}{l}.240 \\
\mathrm{a}\end{array}$ \\
\hline Residual & 2012.734 & 135 & 14.909 & & \\
\hline Total & 2033.504 & 136 & & & \\
\hline
\end{tabular}

a. Predictors: (Constant), Liberationist

b. Dependent Variable: Incivility

As indicated in table 6, the regression of student incivility on the liberationist approach is not statistically significant. This means that the inclusion of the liberationist approach as an independent variable in the multiple regression equation is impossible.

Table 7. Multiple regression models (Enter Method)

\begin{tabular}{|c|c|c|c|c|c|c|c|c|}
\hline \multirow{2}{*}{$\begin{array}{l}\text { Mo } \\
\text { del }\end{array}$} & \multirow[t]{2}{*}{$\mathrm{R}$} & \multirow{2}{*}{$\begin{array}{l}\mathrm{R} \\
\text { Square }\end{array}$} & \multirow{2}{*}{$\begin{array}{l}\text { Adjuste } \\
\text { d R } \\
\text { Square }\end{array}$} & \multicolumn{5}{|c|}{ Change Statistics } \\
\hline & & & & $\begin{array}{l}\mathrm{R} \text { Square } \\
\text { Change }\end{array}$ & $\begin{array}{l}\mathrm{F} \\
\text { Change }\end{array}$ & df1 & $\mathrm{df} 2$ & $\begin{array}{l}\text { Sig. F } \\
\text { Change }\end{array}$ \\
\hline 1 & $.470^{\mathrm{a}}$ & .220 & .215 & .220 & 38.187 & 1 & $\begin{array}{l}13 \\
5\end{array}$ & .000 \\
\hline 2 & $\begin{array}{l}.477 \\
\mathrm{~b}\end{array}$ & .228 & .216 & .007 & 1.285 & 1 & $\begin{array}{l}13 \\
4\end{array}$ & .259 \\
\hline
\end{tabular}

All of the statistics for model 1 are the same as the simple regression model. The next column gives a value of $R^{2}$, which shows how much of the variability in the student Incivility is accounted for by the facilitator approach to teaching. For the first model its value is .220 , 
which means that the facilitator approach to teaching accounts for $22 \%$ of the variation in student incivility. However, when the other two predictors are included as well (model 2), this value increases to .228 of the variance in student incivility. Therefore, if the facilitator approach to teaching accounts for $20 \%$, we can say that the executive approach to teaching accounts for an additional $6 \%$. So the inclusion of a new predictor has explained quite a few of the variation in student incivility.

The adjusted $\mathrm{R}^{2}$ gives some idea of how well the model generalizes and ideally its value is expected to be the same or very close to, the value of $\mathrm{R}^{2}$.

The difference between $\mathrm{R}^{2}$ and adjusted $\mathrm{R}^{2}$ for the final model is small (in fact the difference between the values is $.228-.216=.012$ (about $0.12 \%$ ). This shrinkage means that if the model were derived from the population rather than a sample, it would account for approximately $0.12 \%$ less variance in the outcome.

Table 8. ANOVA

\begin{tabular}{|c|c|c|c|c|c|c|}
\hline \multicolumn{2}{|c|}{ Model } & \multirow{2}{*}{$\begin{array}{l}\begin{array}{l}\text { Sum of } \\
\text { Squares }\end{array} \\
448.380\end{array}$} & \multirow{2}{*}{$\begin{array}{l}\text { df } \\
1\end{array}$} & \multirow{2}{*}{$\begin{array}{l}\begin{array}{l}\text { Mean } \\
\text { Square }\end{array} \\
448.380\end{array}$} & \multirow{2}{*}{$\begin{array}{l}\text { F } \\
38.187\end{array}$} & \multirow{2}{*}{$\begin{array}{l}\text { Sig. } \\
.000^{\mathrm{b}}\end{array}$} \\
\hline 1 & $\begin{array}{l}\text { Regressio } \\
\mathrm{n}\end{array}$ & & & & & \\
\hline & Residual & 1585.124 & 135 & 11.742 & & \\
\hline & Total & 2033.504 & 136 & & & \\
\hline \multirow[t]{3}{*}{2} & $\begin{array}{l}\text { Regressio } \\
n\end{array}$ & 463.433 & 2 & 231.716 & 19.776 & $.000^{\mathrm{c}}$ \\
\hline & Residual & 1570.071 & 134 & 11.717 & & \\
\hline & Total & 2033.504 & 136 & & & \\
\hline
\end{tabular}

a. Dependent Variable: Incivility

b. Predictors: (Constant), Facilitator

c. Predictors: (Constant), Facilitator, Executive

For the initial model the F-ratio is 38.187 ( $\mathrm{p}<0.001)$. For the second model the value of $\mathrm{F}$ is lower (19.776), but it is also significant $(\mathrm{p}<0.001)$. These results indicate that the initial model is effective in predicting the outcome variable (student incivility); but that the new model with the extra predictor (Executive approach) is even better. Although F-ratio has decreased in second model, it is apparently preferred to the first model because it includes another illuminative variable which enables us to provide better explanations. 
Table 9. Coefficients

\begin{tabular}{|c|c|c|c|c|c|c|c|c|}
\hline \multirow{2}{*}{\multicolumn{2}{|c|}{ Model }} & \multicolumn{2}{|c|}{$\begin{array}{l}\text { Unstandardized } \\
\text { Coefficients }\end{array}$} & \multirow{2}{*}{$\begin{array}{l}\text { Standardiz } \\
\text { ed } \\
\text { Coefficien } \\
\text { ts }\end{array}$} & \multirow[t]{2}{*}{$\mathrm{t}$} & \multirow[t]{2}{*}{ Sig. } & \multicolumn{2}{|c|}{$\begin{array}{l}95.0 \% \text { Confidence } \\
\text { Interval for B }\end{array}$} \\
\hline & & B & $\begin{array}{l}\text { Std. } \\
\text { Error }\end{array}$ & & & & $\begin{array}{l}\text { Lower } \\
\text { Bound }\end{array}$ & $\begin{array}{l}\text { Upper } \\
\text { Bound }\end{array}$ \\
\hline \multirow[t]{2}{*}{1} & $\begin{array}{l}\text { (Consta } \\
\mathrm{nt})\end{array}$ & $\begin{array}{l}36.31 \\
5\end{array}$ & 1.745 & & $\begin{array}{l}20.8 \\
14 \\
\end{array}$ & $\begin{array}{l}.00 \\
0\end{array}$ & 32.864 & 39.765 \\
\hline & $\begin{array}{l}\text { Facilita } \\
\text { tor }\end{array}$ & -.249 & .040 & -.470 & $\begin{array}{l}-6.1 \\
80\end{array}$ & $\begin{array}{l}.00 \\
0\end{array}$ & -.328 & -.169 \\
\hline 2 & $\begin{array}{l}\text { (Consta } \\
\mathrm{nt})\end{array}$ & $\begin{array}{l}33.57 \\
1\end{array}$ & 2.983 & & $\begin{array}{l}11.2 \\
53\end{array}$ & $\begin{array}{l}.00 \\
0\end{array}$ & 27.670 & 39.471 \\
\hline & $\begin{array}{l}\text { Facilita } \\
\text { tor }\end{array}$ & -.241 & .041 & -.455 & $\begin{array}{l}-5.9 \\
04\end{array}$ & $\begin{array}{l}.00 \\
0 \\
\end{array}$ & -.322 & -.160 \\
\hline & $\begin{array}{l}\text { Executi } \\
\text { ve }\end{array}$ & .054 & .048 & .087 & $\begin{array}{l}1.13 \\
3\end{array}$ & $\begin{array}{l}.25 \\
9\end{array}$ & -.040 & .148 \\
\hline
\end{tabular}

The regression coefficients in table 9 indicate that only one significant predictor has positive b-value indicating positive relationship. Thus, as instructors' scores in the facilitator approach increase, students' incivilities decrease. Therefore, it can be concluded that the facilitator approach is the only variable which predicts student incivility in the classrooms.

\section{Discussion}

The analysis of the data revealed that of the teaching approaches, the facilitator approach has a significant relationship with student incivility in the classroom. More specifically, the closer the instructional orientations of the teachers to the foundations of the facilitator approach to teaching, the fewer reported student incivility by instructors. Further investigation of this finding is required. The first point is that in the complementary analyses of the data, no statistically significant relationship was found between student incivility in the classroom and the variables of age, gender, years of teaching experience, and the number of students in each classroom (of course the results indicated that female instructors appeared to show more inclinations towards the facilitator approach). During the process of data analyses, the researchers expected to find a significant difference or relationship between the aforementioned variables, yet the results did not show such a relationship. However, a significant relationship related to one of the teaching approaches was found. This result implies that teaching approaches are influential variables which are more effective than any other variables. Second, in the current study, students' incivilities are reported by the instructors themselves. Therefore, it is not unlikely that the teacher's inclination towards one or a combination of teaching approaches influence his or her conception of student incivility. 


\section{Mll Macrothink}

International Journal of English Language Education

ISSN 2325-0887

2013, Vol. 1, No. 1

In other words, the researchers believe that students' incivilities are prevalent events in every classroom. Nevertheless, instructors' instructional perspectives can influence their conceptions of examples of student incivility and the rate of incivilities in the classroom. As a matter of fact, facilitative teachers might not notice a lot of students' incivilities at all, or might have a totally different interpretation of incivilities due to their awareness of the learners and the main purposes of education. It may also be possible to generalize this explanation to other teachers with different teaching approaches. In fact, an instructor's belief in a certain instructional school of thought can deeply influence his or her conception of students' incivilities in a way that he or she does not even notice these incivilities in the classroom.

\section{References}

Amada, G. (1995). The disruptive college student: Some thoughts and considerations. Journal of College Student Health, 43, 232-236.

Amada, G. (1997). The disruptive college student: Some thoughts and considerations. Journal of College Student Psychotherapy, 11, 57-67.

Amada, G. (1999). Coping with Misconduct in the College Classroom. Asheville, N.C.: College Administration Publications.

Appleby, D, C. (1990). Faculty and Student Perceptions of Irritating Behaviors in the College Classroom. Journal of Staff Program and Organizational Development, 8(2),41-46.

Barbetta, P. M., Norona, K. L., \& Bicard, D. F. (2005). Classroom behavior management: a Dozen common mistakes and what to do instead. Preventing School Failure, 49(3), 11-19.

Banning, M. (2005). Approaches to teaching: current opinions and related research. Nurse Education Today, 25(7), 502-508.

Barr, R. B., \& Tagg, J. (1995). From teaching to learning--a new paradigm for undergraduate education. (cover story). Change, 27(6), 12.

Boice, R. (1992). The new faculty member. San Francisco: Jossey-Bass.

Boice, B. (1996). Classroom Incivilities. Research in Higher Education, 37, 453-486.

Bottoms. Anthony, E. (2006). Incivilities, Offence and Social Order in Residential Communities. In: Andrew Von Hirsch \& Ap Simester. Incivilities: Regulating Offensive Behaviour. New York: Hart Publishing.

Bray, N. J., \& Del Favero, M. (2004). Sociological Explanations for Faculty and Student Classroom Incivilities. New Directions for Teaching and learning.

Charles, C. M. (2008). Building classroom discipline. Boston: Pearson.

Charlton, T. (2003). Managing Misbehaviors in Schools. London: Taylor \& Francis.

Chickering, A. W., \& Gamson, Z. f. (1999). Development and adaptations of the seven principles for good practice in undergraduate education. New Directions for Teaching and Learning, 80, 75-81. 


\section{Macrothink}

International Journal of English Language Education

ISSN 2325-0887

2013, Vol. 1, No. 1

Cohen, J. (1988). Statistical power analysis for the behavioral sciences (2nd ed.). Hillsdale, NJ: Erlbaum.

Connelly, F. M., \& Ben-Peretz, M. (1980). Teachers' Roles in the Using and Doing of Research and Curriculum Development. Journal Of Curriculum Studies, 12(2), 95-107.

Connelly, F. M., \& Elbaz, F. (1980). Conceptual Bases for Curriculum Thought: A teacher's Perspective. In Considered Action for Curriculum Thought, Fashay, A. W., Yearbook of the Association for Supervision and Curriculum Development, Alexandria, VA, ASCD.

Ennis, C. D. (1996). When avoiding confrontation leads to avoiding content: disruptive student students impact on curriculum. Journal of Curriculum and Supervision, 11, 145-162.

Erdfelder, E., Faul, F., \& Buchner, A. (1996). G*POWER: A general power analysis program. Behavior Research Methods, Instruments, \& Computers, 28, 1-11.

Feldmann, L. J. (2001). Classroom Civility Is Another of Our Instructor Responsibilities. College Teaching, 49, 137-140.

Fenstermacher, G. D., \& Soltis, J. F. (2004). Approaches to Teaching. 1234 Amesterdam Avenue, New York, NY 10027, Teachers College press.

Freeman, D., \& Richards, J. C. (1993). Conceptions of Teaching and the Education of Second Language Teachers. TESOL Quarterly, 27, 193-216.

Gage, N. L. (2009). A Conception of Teaching. Stanford, CA: Springer.

Glasser, W. (1998). Choice theory: A new psychology of personal freedom. New York: Harper Collins.

Goodyear, R, Reynolds, P., \& Gragg, J. B. (2010). University faculty experiences of classroom incivilities: a critical incident study. Paper presented at the annual American Education Research Association, Denver, CO.

Grasha, A. F. (2002). Teaching With Style: A Practical Guide to Enhancing Learning by Understanding Teaching and Learning Styles, Alliance Publishers.

Gutek, Gerald. L. (2006). Philosophical and Ideological Perspective on Education (3rd ed.). NJ: Prentice-Hall.

Harris, Z.M. (1996). Institutional transformation. Paper presented at the Annual Meeting of the North Central Administration.

Hawthorne, R. (1990). Analyzing school-based collaborative curriculum decision making, Journal of Curriculum and Supervision, 5(3), 279-286.

Hernandez ,T. J., \& Fister, D. L. (2001). Dealing with disruptive and emotional college students: a systems model. Journal of College Counseling, 4, 49-62.

Hirschy, A.S., \& Braxton, J.M. (2004). Effects of student classroom incivilities on Students. New directions for teaching and learning, 99, 67-76.

Jarvis, P. (2006). The theory \& practice of teaching. New York: Routledge. 
Jarvis-Selinger, S., Collins, J. \& Pratt, D. (2007). Do academic origins influence perspectives on teaching. Teacher Education Quarterly, Summer, 67-81.

Kember, D., \& Gow, L. (1994). Orientations to teaching and their effect on the quality of student learning. Journal of Higher Education, 65, 58-74.

Lam, B. H., Kember, D. (2006). The relationship between conceptions of teaching and approaches to teaching. Teachers and Teaching: theory and practice, 12, 693-713.

Lindblom-Ylänne, S., Trigwell, K., Nevgi, A., \& Ashwin, P. (2006). How approaches to teaching are affected by discipline and teaching context. Studies in Higher Education, 31, 285-298.

Lippmann, S., Bulanda, R. E., and Wagenaar, T. C. (2009). Student entitlement: Issues and strategies for confronting entitlement in the classroom and beyond. College Teaching, 57(4), 197-203.

Merrett, F., \& Wheldall, K. (1984). Classroom behaviour problems which junior primary school teachers find most troublesome. Educational Studies, 10, 87-92.

Meyers, S.A (2003). Strategies to prevent and reduce conflict in college classrooms. College Classrooms, (51), 94-98.

McCutcheon, G. (1985). Curriculum theory/curriculum practice: a gap or the Grand Canyon? In A. Molnar, Ed., Current thought on curriculum. Alexandria, VA: ASCD .

Morrissette, P. J. (2001). Reducing incivility in the university/college classroom. International Electronic Journal for Leadership in Learning, 5, 4. Retrieved November 29, 2012 from www.ucalgary.ca/ iejll

Morrone, A., \& Tarr, T. (2005). Theoretical eclecticism in the college classroom. Innovative Higher Education, 30(1), 7-21.

Murphy, P. D., \& Brown, M. M. (1970). Conceptual System and Teaching Styles. American Educational Research Journa, 7, 529-540.

Oblinger, D. (2003). Boomers, gen x-ers and millenials: understanding the new students. Educause, 37-47.

Pratt, D. D. (1992). Conceptions of teaching. Adult Education Quarterly, 42(4), 203-220.

Pratt, D. D. (1997). Reconceptualizing the evaluation of teaching in higher education. Higher Education, 34, 23-44.

Pratt, D. D., \& Associates. (1998). Five perspectives on teaching in adult and higher education. Malabar, FL: Krieger, Publishers.

Pratt, D. D., \& Collins, J. B. (2001, June). The Teaching Perspectives Inventory (TPI). Paper presented at the Adult Education Research Conference, Vancouver, BC.

Prosser, M., Trigwell, K., \& Taylor, P. (1994). A phenomenographic study of academics' conceptions of science learning and teaching. Learning and Instruction, 4(3), 217-231.

Prosser, M., \& Trigwell, K. (1999). Understanding learning and teaching. The experience in 


\section{Macrothink \\ International Journal of English Language Education \\ ISSN 2325-0887 \\ 2013, Vol. 1, No. 1}

higher education. Buckingham: Open University Press.

Richardson, S.M. (1999). Civility, leadership and the classroom. New Directions of Teaching and Learning, 77, 77-86.

Ridley, D. S., \&Walther, B. (1995). Creating Responsible Learners: The role of a Positive Classroom Environment, Washington, DC: American Psychology Association.

Seidman, A. (2005). The learning killer: Disruptive student behavior in the classroom. Reading Improvement. 42, 40-6.

Shin, S., \& Koh, M., (2007). A Cross-Cultural Study of Teachers' Beliefs and Strategies on Classroom Behavior Management in Urban American and Korean School Systems. Education and Urban Society, 39, 286-309.

Sorcinelli, M.D. (1994). Dealing with Troublesome Behaviors in the Classroom. In K.W. Prichard \& R. M. Sawyer (Eds.), Handbook of college teaching: Theory and Applications. New York: Greenwood Press. (pp. 365-373).

Trigwell, Keith, \& Prosser, Michael. (1991). Improving the Quality of Student Learning: The Influence of Learning Context and Student Approaches to Learning on Learning Outcomes. Higher Education, 22(3), 251-266.

Trigwell, K., Prosser, M., \& Taylor, P. (1994). Qualitative Differences in Approaches to Teaching First Year University Science. Higher Education, 27(1), 75-84

Trigwell, K., \& Prosser, M. (1996 a). Congruence between intention and strategy in science teachers' approach to teaching. Higher Education, 32, 77-87.

Trigwell, K., Prosser, M., \& Waterhouse, F., (1999). Relations between Teachers' Approaches to Teaching and Students' Approaches to Learning. Higher Education, 37(1), 57-70.

Weimer, M. E. (1988). Ideas for managing your classroom better. The Teaching Professor, 2(2), $3-4$.

Wentzel, K. R. (2002). Are Effective Teachers like Good Parents? Teaching Styles and Student Adjustment in Early Adolescence. Child Development, 73, 287-301.

Young, J. R. (2003). Sssshhh. We're talking here. The Chronicle of Higher Education, 48, 49, 29-30.

\section{Copyright Disclaimer}

Copyright reserved by the author(s).

This article is an open-access article distributed under the terms and conditions of the Creative Commons Attribution license (http://creativecommons.org/licenses/by/3.0/). 